\title{
The Comparative Study of the Strategic IS Planning Practices in Slovenia and Singapore
}

\author{
Andrej Kovačič, Aleš Groznik, Jurij Jaklič, Mojca Indihar Stemberger \\ University of Ljubljana, Faculty of Economics, Slovenia
}

\begin{abstract}
The paper presents the results of the survey on the strategic IS planning practices of Slovene large organizations. The survey was based on the questionnaire previously developed in Singapore, and the results of both countries, one developed and the other in transition, are compared. It highlights the participation, critical success factors, initiators and the main benefits of the strategic IS planning. The results compared to similar studies show a very low number of companies which perform the strategic IS planning. It is also interesting that top management plays the role of a leading initiator in Slovene organizations whereas the role of IS management is surprisingly modest. The main benefits of the strategic IS planning from the Slovene business perspective are: improved internal co-ordination, efficient and effective management of IS resources and improved productivity.
\end{abstract}

Keywords: strategic planning, SISP, survey, questionnaire

\section{Introduction}

A lot of research has been done which focuses on identifying key IT issues concerning corporate transformation. Technical progress together with the opening of a global market are definitely among the primary factors which play important roles in a modern society. IT is an essential component of a firm's strategy used in a global market. One of the consequences of the recent development in the field of information technology is an ongoing process of planning in both the IS and business areas. In Slovenia, as well in other economies in transition, there is a significant lack of research in the area of strategic IS planning.

Slovene organizations react very differently to projects or attempts of introducing modern IT and renovation of business processes, though the purpose is clear: reduction of costs, shortening of the business cycle, and improvement of quality. The difficulties in the public sector are larger than those in the private sector. The increased employment in the public sector during the past few years has further entrenched bureaucracies. As a result, the problems of efficiency are most often solved by purchasing computer hardware and software. Moreover, if managers feel their corporations are successful at present, they usually reject the idea of strategic IS planning and renovating the business. Of course, when an organization faces trouble, there never seems to be enough financial or human resources to start such a project. While we were working on IS renovation projects in the last few years, we noticed (Kovačič, 1999) that IT plays the key role in business process renovation and that there is a strong correlation between the quality of IS within an organization and the improvement of an overall corporate culture and the organizations' strategies (Lederer and Sethi, 1996). We must also keep in mind that an incorrect or inadequate strategic IS planning can bring partial solutions where the system is not considered as a whole, which makes these solutions unsatisfactory.

Since a large proportion of studies on the strategic IS planning are based on case-oriented research, researchers have found it difficult to generalize their results across a wide variety of organizations. After the study objectives and concerns for external validity and generalization had been evaluated, a survey questionnaire was 
determined to be the most appropriate research methodology for this study. The study was performed by the MIS Department of the Faculty of Economics in Ljubljana in 1998 and was based on a questionnaire (included in the appendix) that was previously developed by (Conrath, Ang and Mattey, 1992) and (McLean and Soden, 1977), (Pavri and Ang, 1995), (Teo, Ang and Pavri, 1997). The questionnaire covered all areas we were planning to research and, above all, it provided us with a useful set of results on the strategic IS planning practices in Singapore which served as a valuable comparison analysis. Table 1 shows the comparison of Singaporean and Slovenian business environment.

This paper focuses only on the IS strategic planning part of the questionnaire which covers the following topics:

- The comparison of the macro-organizational features of those Slovenian organizations that undertook IS strategic planning and those that did not

- The participation in the strategic IS planning

- The critical success factors of the strategic IS planning

- The benefits of the strategic IS planning

- Organization and MIS Department degree of maturity

- Other relevant strategic IS planning data (e.g. planning methodology, corporate and strategic IS planning alignment).

The rest of our study covered general information about an organization, its structure and general state of the IS, the architecture of the IS and the underlying technology, the state of databases and data warehouses. Some results on other parts were published (Jaklič et al., 1999a), (Jaklič et al., 1999b). We plan to carry out the survey every two years, which will help us compare the results and observe current trends in Slovene organizations over a longer timeframe.

The rest of the paper is organized as follows: Section 2 presents the methodology and section 3, which is divided into several subsections, presents the results compared with results from Singapore. Some important similarities and differences that have been found are pointed out. The last section contains the conclusion with some interpretation of findings through the economical background of Slovenian organizations. Some plans for our future work are also stated.

\section{Methodology}

The survey was based on the questionnaire previously developed by (Conrath, Ang and Mattey, 1992) and (McLean and Soden, 1977). The questionnaire was supplemented and successfully used in the survey in Singapore (Pavri and Ang, 1995) and (Teo, Ang and Pavri, 1997). Since we wanted to compare the results, we used the same questionnaire as (Teo, Ang and Pavri, 1997) but it was of course translated into Slovene language . Since we made use of an existing instrument, we did not investigate its reliability and validity.

Our target population included 450 large Slovene organizations taken from a wide range of indus-

\begin{tabular}{|l|c|c|}
\hline & Singapore & Slovenia \\
\hline \hline Land Area (sq. km) & 647.8 & 20,273 \\
Total Population & $3,736.700$ & $1,978.334$ \\
Gross Domestic Product (\$ billion) & 94,602 & 21,426 \\
GDP growth (\%) & 6.0 & 4.9 \\
Labour Productivity (\%) & 2.2 & 3.3 \\
Unemployment Rate (\%) & 1.7 & 7.7 \\
Exports (\$m) & 125,000 & 9,500 \\
Imports (\$m) & 132,400 & 10,100 \\
\hline
\end{tabular}

Table 1. Singapore (in 1997, Statistics Singapore) and Slovenia (estimated in 1999, Slovenia in Figures) top-line economic indicators. 
tries, randomly chosen from the Register of Organizations (Register of Organizations, 1998), a register of all organizations in Slovenia. The inquiry was being performed from July 1998 to December 1998. In order to ensure that the responses reflect the organizations' perspective of the strategic IS planning, the IS executives were asked to answer the questionnare. The questionnaires were distributed by mail and the answers were obtained by mail or with the help of the web-based application. All answers were collected in the same database. There was some verbal communication between the companies and authors, which was mostly concerned with the organizations expressed some doubts about the confidence of information, but it did not influence the results.

The questionnaire was pre-tested with the postgraduate and doctoral students for content validity, comprehensiveness and readability. After the feedback from pre-testing has been obtained, the questionnaire was pilot tested with five senior IS executives.

A total of 131 useful answers to the strategic IS planning part were obtained, representing the database on the strategic IS planning practices in Slovenia. The rate of the return was $29 \%$ and is comparable to the similar studies (Karimi, Gupta and Somers, 1996), (Lederer and Sethi, 1996), (Pavri and Ang, 1995), (Teo, Ang and
Pavri, 1997), (Torkzadeh and Xia, 1992) conducted in the past where the rate of the return reached $21 \%, 24 \%, 22 \%, 20 \%$ and $23 \%$ respectively.

Table 2 shows the structure of the organizations according to the number of employees and their activities. The activities in the category Miscellaneous are of a different kind such us consulting, transport, IT, catering, tourism, health service, government, telecommunications. The sample is comparable to the Singaporean sample regarding these two parameters as evident from the Table 2. The respondents were also reasonably well distributed according to the types of business and number of employees, which can be compared to the distribution of all Slovenian large companies (Slovenia in Figures '99, 2000), (GV-in, 2000). Therefore we can generalize the results of the survey to the population of large companies in Slovenia.

The performed data analysis was the same as in the Singaporean survey. MS Excel was used for the analyses of the answers. The results in the next section are presented in tables, in case there is a lot of data to be presented graphs are used to increase the imagination of numbers.

\begin{tabular}{|l|ccc|cc|}
\hline & \multicolumn{3}{|c|}{ Present study } & \multicolumn{2}{c|}{ Teo et al. } \\
\hline \hline & Number & Percentage & $\begin{array}{c}\text { Slovenian } \\
\text { large } \\
\text { organizations }\end{array}$ & Number & Percentage \\
\hline \hline Structure by type of business & 54 & $41.4 \%$ & $36.5 \%$ & 23 & $32.9 \%$ \\
Manufacturing & 22 & $17.1 \%$ & $12.0 \%$ & 6 & $8.6 \%$ \\
Retail and Wholesale & 9 & $7.2 \%$ & $3.2 \%$ & 18 & $25.7 \%$ \\
Finance and Insurance & 45 & $34.3 \%$ & $48.3 \%$ & 22 & $31.4 \%$ \\
Miscellaneous & 0 & $0 \%$ & & 1 & $1.4 \%$ \\
No Response & & & & & \\
\hline Structure by total number & & & & & \\
of employees & 29 & $22.1 \%$ & $14.9 \%$ & 13 & $18.6 \%$ \\
$<100$ & 53 & $40.5 \%$ & $43.5 \%$ & 20 & $28.6 \%$ \\
$101-500$ & 23 & $17.6 \%$ & $24.8 \%$ & 13 & $18.6 \%$ \\
$501-1000$ & 26 & $19.8 \%$ & $16.8 \%$ & 20 & $28.6 \%$ \\
$>1000$ & 0 & $0 \%$ & & 4 & $5.7 \%$ \\
No Response & \multicolumn{7}{|c|}{} & &
\end{tabular}

Table 2. Structure of organizations. 


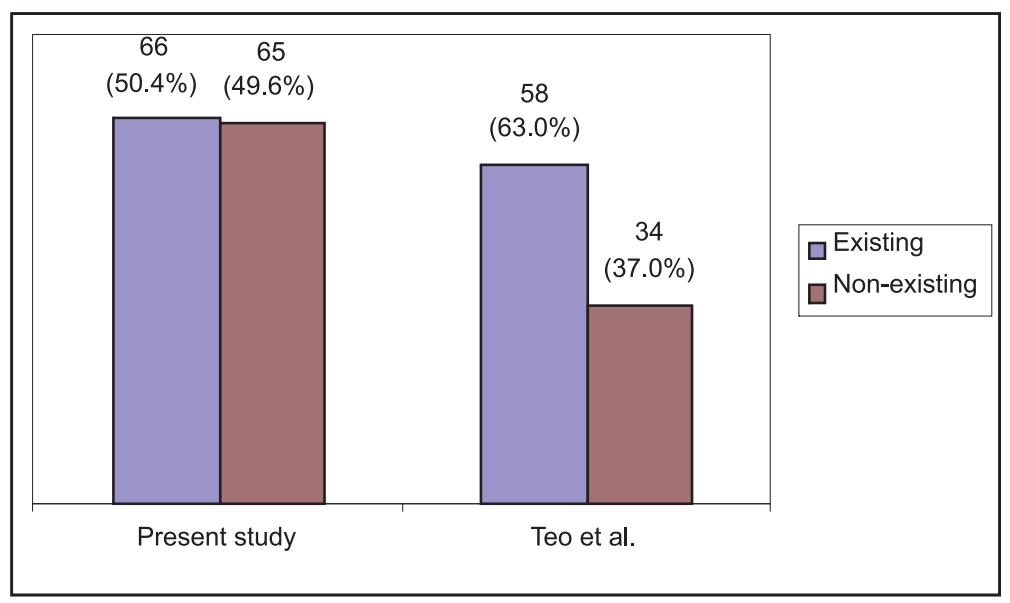

Fig. 1. IS strategic plan implementation (answers to question 1).

\section{Results}

The analysis of the returned questionnaires shows that over $50 \%$ of the responding companies performed some form of the strategic IS planning process. As can be seen from Figure 1, the relationship in Teo et al's study was better because $63 \%$ of companies implemented some form of strategic IS planning process. This is especially worrying since Teo et al's study was performed two years earlier.

As evident from the Table 3 the number of firms that carried out the strategic IS planning increases directly with the total number of employees. Similar relationship was found in Teo et al's study where significant relationships were found also between strategic IS planning and annual sales revenue. In our investigation the latter was not found significant $(\mathrm{df}=2$, chisquare $=2.7660, \mathrm{p}<0.2508)$. On the contrary, there exists a strong relationship between the strategic IS planning and organization structure which was not found in Singapore.

\subsection{IS Strategic Plan/Corporate Plan}

As it has already been presented in the past, the key to the success of the strategic IS planning process is in the corporate and strategic IS plan alignment (Clarke, 1992), (Lederer and Sethi, 1996), (Lederer and Salmela, 1996). Although

\begin{tabular}{|c|c|c|c|c|c|c|c|c|}
\hline & \multicolumn{4}{|c|}{ Present study } & \multicolumn{4}{|c|}{ Teo et al. } \\
\hline & $\begin{array}{c}\text { Sample } \\
\text { Size }\end{array}$ & Yes & No & $\begin{array}{l}\text { Result of Chi- } \\
\text { Square Test }\end{array}$ & $\begin{array}{c}\text { Sample } \\
\text { Size }\end{array}$ & Yes & No & $\begin{array}{l}\text { Result of Chi- } \\
\text { Square Test }\end{array}$ \\
\hline $\begin{array}{l}\text { Total Number } \\
\text { of Employees } \\
<100 \\
101-500 \\
501-1000 \\
>1000\end{array}$ & 131 & $\begin{array}{l}13 \\
20 \\
15 \\
18\end{array}$ & $\begin{array}{c}16 \\
33 \\
8 \\
8\end{array}$ & $\begin{array}{c}\mathrm{DF}=3 \\
\text { Chi-square = } \\
9.4685 \\
p<0.0237\end{array}$ & 66 & $\begin{array}{c}2 \\
8 \\
8 \\
13\end{array}$ & $\begin{array}{l}11 \\
12 \\
5 \\
7\end{array}$ & $\begin{array}{c}\mathrm{DF}=3 \\
\text { Chi-aquare }= \\
9.315 \\
p<0.025\end{array}$ \\
\hline $\begin{array}{l}\text { Physical Organisation } \\
\text { Structure } \\
\text { Centralized } \\
\text { Decentralized }\end{array}$ & 129 & $\begin{array}{l}16 \\
49\end{array}$ & $\begin{array}{l}37 \\
27\end{array}$ & $\begin{array}{c}\mathrm{DF}=1 \\
\text { Chi-square }= \\
14.6823 \\
p<0.001\end{array}$ & 67 & $\begin{array}{l}12 \\
19\end{array}$ & $\begin{array}{l}19 \\
17\end{array}$ & $\begin{array}{c}\mathrm{DF}=1 \\
\text { Chi-square }= \\
1.33 \\
p<0.250\end{array}$ \\
\hline
\end{tabular}

Table 3. Relationship between macro-organizational variables and strategic IS plan. 


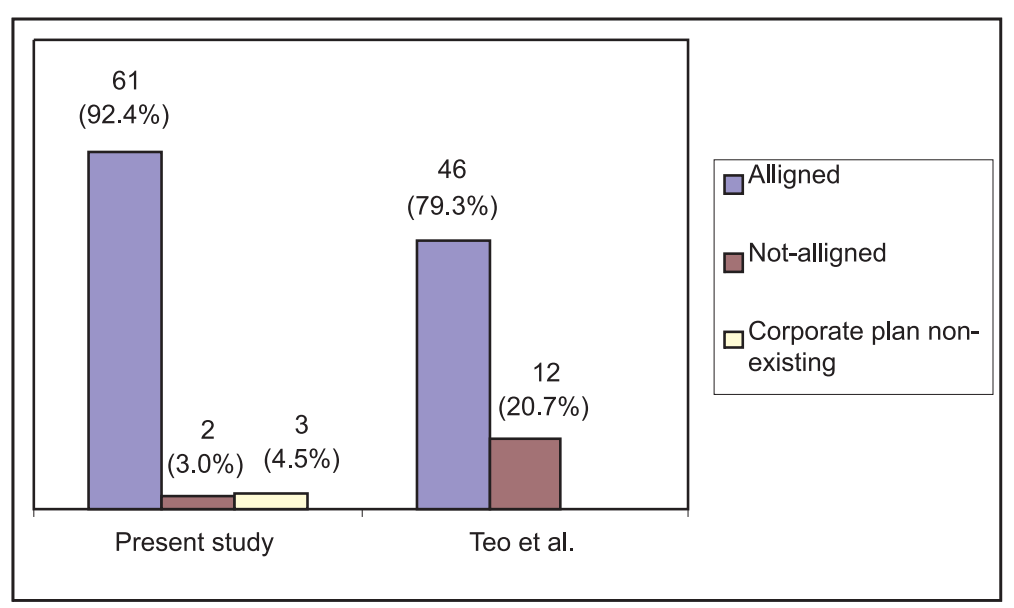

Fig. 2. Corporate and strategic IS plan alignment (answers to question 10).

the rate of companies conducting the strategic IS planning in Slovenia is much lower than the one in Singapore, it is surprising that the corporate and strategic IS plans are aligned in a much higher rate $(92.4 \%$ compared to Teo et al's $79.3 \%$ ) as shown in Figure 2.

Furthermore, in the majority of companies $(96.9 \%$ in the present study, $93.1 \%$ Teo et al's), the IS strategic plan developers show a high level of awareness of corporate objectives. Such results suggest that those companies that perform the strategic IS planning have realized the importance of corporate and strategic IS plan alignment as the key to the successful role of IT in business environment.

\subsection{Planning Methodologies/Participants in Strategic IS Planning}

In Table 4 the planning methodologies used by companies are compared. Only the respondents that have the strategic IS plan answered this question and the rest of the questionnaire.
$60 \%$ of the respondents (compared to Teo et al's $69 \%$ ) stated that they used a combination of top-bottom and bottom-up planning methodologies. In addition, $36.9 \%$ of the respondents (compared to Teo et al's 19\%) used top-down planning approach. This result suggests that the combination of different methodologies prevails as the most common strategic IS planning methodology, as it enables the synergy of business and user involvement.

Contrary to Teo et al's finding, our results suggest that the top-down approach is more widely used in Slovenia. This indicates that the strategic IS planning in Slovenia is still a traditionally oriented process in which management plays a very important role. The degree of participation in the strategic IS planning can be depicted from Table 5. The results for Slovenia show that in the strategic IS planning, the top and MIS management play the predominant role (on the scale from 1 to 4, 3.92 and 3.43 respectively in the present study compared to Teo et al's 3.79 and 3.36) compared to users' involvement (2.55

\begin{tabular}{|l|ccc|ccc|}
\hline Planning methodologies & \multicolumn{3}{|c|}{ Present study } & \multicolumn{3}{c|}{ Teo et al. } \\
\cline { 2 - 7 } & Number & Percentage & Rank & Number & Percentage & Rank \\
\hline \hline Bottom-up & 2 & $3.1 \%$ & 3 & 7 & $12.1 \%$ & 3 \\
Top-down & 24 & $36.9 \%$ & 2 & 11 & $19.0 \%$ & 2 \\
Combination of above & 39 & $60.0 \%$ & 1 & 40 & $69.0 \%$ & 1 \\
No answer & 0 & $0.0 \%$ & 4 & 0 & $0.0 \%$ & 4 \\
Total & 65 & $100.0 \%$ & & 58 & $100.0 \%$ & \\
\hline
\end{tabular}

Table 4. Strategic IS planning methodologies (answers to question 9). 


\begin{tabular}{|l|cccc|ccc|}
\hline \multirow{2}{*}{ Participants (scale from 1 to 4) } & \multicolumn{4}{|c|}{ Present study } & \multicolumn{3}{c|}{ Teo et al. } \\
\cline { 2 - 9 } & Number & Mean & S.D. & Rank & Mean & S.D. & Rank \\
\hline \hline MIS managers & 64 & 3.92 & 0.32 & 1 & 3.79 & 0.59 & 1 \\
Top managers & 65 & 3.43 & 0.76 & 2 & 3.36 & 0.74 & 2 \\
System analysts (developers) & 55 & 3.20 & 0.86 & 3 & 2.75 & 0.88 & 4 \\
Non-MIS managers & 63 & 3.02 & 0.85 & 4 & 2.58 & 0.84 & 5 \\
Consultants & 62 & 2.92 & 1.05 & 5 & 1.89 & 0.92 & 9 \\
Computer systems programmer & 62 & 2.77 & 0.99 & 6 & 2.29 & 1.02 & 6 \\
Computer operations personnel & 57 & 2.56 & 0.94 & 7 & 2.05 & 0.91 & 7 \\
Users & 64 & 2.55 & 0.90 & 8 & 2.80 & 0.80 & 3 \\
Vendors & 58 & 2.36 & 1.03 & 9 & 2.02 & 0.86 & 8 \\
\hline
\end{tabular}

Table 5. Participants in strategic IS planning (answers to question 12).

compared to Teo et al's 2.8) where they are surprisingly rated at the very bottom.

If we compare the strategic IS planning methodologies and participants we can conclude that the combination of both, top-bottom and bottomup, planning methodologies still prevails. A high involvement of the top and MIS management and the significant lack of users' participation result in a high rate of top- down approach.

\subsection{Critical Success Factors}

Among 10 critical success factors listed, the first 4 in our study were related to the importance of management involvement and support as well as human resources-related issues.

Getting the top management support for the planning efforts ( 4.83 in the present study, 4.69 Teo et al) with having a clear-cut corporate plan guide strategic IS planning efforts (4.52 in the present study, 4.41 Teo et al) represent the key factors for the successful strategic IS planning in the literature (Clarke, 1992), (Karimi, Gupta and Somers, 1996), (Lederer and Sethi, 1996).

The ability to obtain sufficient qualified personnel ranks as the second most important critical success factor in the strategic IS planning personnel in Slovenia (4.59 in the present study, 4.22 Teo et al). We believe that the reason for this deviation is a significant shortage of qualified resources which would support increasing evolution and the spread of information technology.

The fourth most important critical success factor is having a good user-IS relationship (4.38 in the present study, 4.22 Teo et al). This relationship is crucial for achieving the strategic objectives. Users and IS staff should act as partners in meeting the strategic objectives which would lead the organization to an operational excellence as was already proved in the past (Karimi, Gupta and Somers, 1996), (Lederer and Sethi, 1996), (Lederer and Salmela, 1996), (Porter, 1985). Other success factors (see Table 6) are mainly related to planning (i.e. time management, environmental changes, planning procedure, etc).

\subsection{Benefits/Satisfaction with Strategic IS Plan}

The respondents were asked to rate the degree of benefits derived from the strategic IS planning process on a five-point scale. According to the results shown in Table 7, the companies highly appreciate the benefits from the strategic IS planning process (on a scale from 1 to 5 , all benefits were rated with a mean of 3.89 or higher). In both studies, the most important benefits were improved internal co-ordination (4.57 in the present study, 4.07 Teo et al), efficient and effective management of IS resources (4.45 in the present study, 4.05 Teo et al) and improved productivity ( 4.37 in the present study, 4.09 Teo et al). It is also interesting to observe that the respondents value internal benefits more than the external ones. The possible reason might be that internal benefits are easily recognized whereas the external ones are not clearly defined. 


\begin{tabular}{|c|c|c|c|c|c|c|c|}
\hline \multirow[t]{2}{*}{ Critical success factors (scale from 1 to 5 ) } & \multicolumn{4}{|c|}{ Present study } & \multicolumn{3}{|c|}{ Teo et al. } \\
\hline & Number & Mean & S.D. & Rank & Mean & S.D. & Rank \\
\hline $\begin{array}{l}\text { Getting top management support for the } \\
\text { planning efforts }\end{array}$ & 64 & 4.83 & 0.38 & 1 & 4.69 & 0.54 & 1 \\
\hline $\begin{array}{l}\text { Being able to obtain sufficiently qualified } \\
\text { personnel to do a proper job }\end{array}$ & 64 & 4.59 & 0.58 & 2 & 4.22 & 0.75 & 3 \\
\hline $\begin{array}{l}\text { Having a clear-cut corporate plan to guide } \\
\text { strategic IS planning efforts }\end{array}$ & 64 & 4.52 & 0.73 & 3 & 4.41 & 0.80 & 2 \\
\hline Having good user-IS relationship & 64 & 4.38 & 0.76 & 4 & 4.22 & 0.68 & 3 \\
\hline $\begin{array}{l}\text { Investing sufficient 'front end' time to ensure } \\
\text { that all planning tasks and individual } \\
\text { responsibilities are well understood }\end{array}$ & 64 & 4.31 & 0.73 & 5 & 3.98 & 0.78 & 8 \\
\hline $\begin{array}{l}\text { Anticipating likely changes in information } \\
\text { technology (and environmental changes) } \\
\text { which might affect the strategic IS planning } \\
\text { process }\end{array}$ & 64 & 4.28 & 0.74 & 6 & 4.10 & 0.67 & 5 \\
\hline $\begin{array}{l}\text { Having free communication and commitment } \\
\text { to change thought of the organization }\end{array}$ & 63 & 4.21 & 0.91 & 7 & 4.02 & 0.81 & 7 \\
\hline $\begin{array}{l}\text { Having a clear, concise and formal planning } \\
\text { procedure }\end{array}$ & 64 & 3.98 & 0.86 & 8 & 4.05 & 0.85 & 6 \\
\hline Deciding on an appropriate planning horizon & 64 & 3.89 & 0.89 & 9 & 3.95 & 0.60 & 9 \\
\hline $\begin{array}{l}\text { Taking into account the people and politics } \\
\text { side of strategic IS planning system }\end{array}$ & 63 & 3.65 & 1.09 & 10 & 3.55 & 0.82 & 10 \\
\hline
\end{tabular}

Table 6. Critical success factors in strategic IS planning (answers to question 15).

\begin{tabular}{|l|rrrr|rrr|}
\hline Benefits from strategic IS planning process & \multicolumn{4}{|c|}{ Present study } & \multicolumn{3}{c|}{ Teo et al. } \\
\cline { 2 - 8 } (scale from 1 to 5) & Number & Mean & S.D. & Rank & Mean & S.D. & Rank \\
\hline \hline Improved internal coordination & 65 & 4.57 & 0.63 & 1 & 4.07 & 0.71 & 2 \\
Efficient and effective management of IS & 65 & 4.45 & 0.66 & 2 & 4.05 & 0.59 & 3 \\
resources & & & & & & & \\
Improved productivity & 65 & 4.37 & 0.81 & 3 & 4.09 & 0.64 & 1 \\
Improved quality in products/services & 65 & 4.23 & 0.87 & 4 & 3.88 & 0.69 & 6 \\
Improved competitive position & 64 & 4.16 & 0.91 & 5 & 4.00 & 0.81 & 4 \\
Sound technology path and policies & 65 & 3.97 & 0.80 & 6 & 3.70 & 0.63 & 7 \\
Larger market share & 63 & 3.90 & 1.00 & 7 & 3.30 & 0.91 & 8 \\
Greater ability to meet changes in the industry & 62 & 3.89 & 1.11 & 8 & 3.89 & 0.76 & 5 \\
\hline
\end{tabular}

Table 7. Benefits from strategic IS planning process (answers to question 16).

\begin{tabular}{|l|ccc|ccc|}
\hline Initiated by & \multicolumn{3}{|c|}{ Present study } & \multicolumn{3}{c|}{ Teo et al. } \\
\cline { 2 - 7 } & Number & Percentage & Rank & Number & Percentage & Rank \\
\hline \hline Top management & 23 & $35.9 \%$ & 1 & 5 & $8.6 \%$ & 4 \\
Top and IS management & 18 & $28.1 \%$ & 2 & 7 & $12.1 \%$ & 3 \\
IS management & 15 & $23.4 \%$ & 3 & 24 & $41.4 \%$ & 1 \\
IS and line management & 3 & $4.7 \%$ & 4 & 3 & $5.2 \%$ & 6 \\
Line (or functional) management & 2 & $3.1 \%$ & 5 & 0 & $0.0 \%$ & 7 \\
Top, IS and line management & 2 & $3.1 \%$ & 5 & 15 & $25.9 \%$ & 2 \\
Missing data & 1 & $1.6 \%$ & 7 & 4 & $6.9 \%$ & 5 \\
\hline
\end{tabular}

Table 8. Initiators of strategic IS planning process (answers to question 17). 
The comparison of the two studies reveals that although the most important benefits match, they were nevertheless ranked differently. The improved productivity, which was the most important benefit in Teo et al's study, ranked only third in the present study. This is somehow interesting because the improved productivity was historically the most important benefit of the strategic IS planning process (Davenport and Linder, 1994), (Karimi, Gupta and Somers, 1996), (Lederer and Salmela, 1996), (Porter, 1985), (Torkzadeh and Xia, 1992) that was clearly underscored in the present study (10 respondents rated the improved productivity below semi-beneficial). This indicates that many Slovene executives perhaps still do not understand the strategic role and benefits of the IS. The traditional thinking using the IS for the internal co- ordination and efficient and effective management support will have to be changed to improve productivity as well as external benefits. The first step towards this change should be a part of the strategic IS planning process.

Similarly to the highly appreciated benefits of the strategic IS planning process, satisfaction with the strategic IS plan also ranked high. Over 98 percent of respondents rated satisfaction with their strategic plan above average.

\subsection{Initiation of Strategic IS Planning Process}

The results presented in Table 8 show that the initiators of the strategic IS planning process vary significantly between Slovenia and Singapore. Whereas Teo at al's study shows the natural rank of initiators (41.4\% IS management; $25.9 \%$ top, IS and line management; $12.1 \%$ top and IS management), our study reveals that in Slovenia the most important initiator of the strategic IS planning process is the top management $(35.9 \%)$, followed by the top and IS management $(28.1 \%)$ and IS management $(23.4 \%)$.

The responses regarding the initiation of the strategic IS planning process confirmed that in Slovenia the strategic IS planning is still a traditionally oriented process in which the top management plays a very important role which is surprising because we would expect IS management to significantly add value to the strategic IS planning due to its expertise.
It also has to be pointed out that the top, IS and line management does not take the joint initiation in Slovenian companies. In fact, the joint management initiation rated last with only $3.1 \%$ in contrast with $25.9 \%$ in Teo et al's study.

\subsection{Evaluation of IS Function}

It is interesting to observe that among companies that practiced the strategic IS planning process, only $(23.1 \%)$ have the objective measures of IS contributions to productivity, although $95 \%$ of the respondents rated the importance of developing such measures with 3 or higher on a scale from 1 to 5 (answers to questions 18 and 19). This result is in line with Teo et al's result that shows that $24 \%$ respondents have objective measures and $98 \%$ rated their importance 3 or higher.

The lack of the objective measures of IS contributions to productivity is also connected to the benefits from the strategic IS planning. Since very few respondents have objective measures of IS contributions to productivity there is no mechanism which would measure the impact on the productivity of business processes resulting in a poor rating of improved productivity as a benefit from the strategic IS planning (Table 7).

Although the results show that the importance of developing objective measures is recognized by the companies, it has not been implemented in practice yet. It will be very interesting to see how this subject is going to develop in the future since the impact of the information technology on productivity remains an important benefit.

\subsection{Organization's Degree of Maturity}

The organization's degree of maturity has been evaluated through a long range business planning, capital allocation and objective setting (Table 9). It is very encouraging that the majority $(84.6 \%$ in the present study, $72.4 \%$ Teo et al) of the responding companies perform a long range business planning in either more tactical than strategic $(47.7 \%$ in the present study, $37.9 \%$ Teo et al) or clearly strategic nature (36.9\% in the present study, $34.5 \%$ Teo et al).

In both studies, the financial aspect of the capital allocation is significant since the majority of respondents $(95.4 \%$ in the present study, $91.4 \%$ 


\begin{tabular}{|c|c|c|c|c|c|c|}
\hline \multirow[t]{2}{*}{ Degree of maturity } & \multicolumn{3}{|c|}{ Present study } & \multicolumn{3}{|c|}{ Teo et al. } \\
\hline & Number & Percentage & Rank & Number & Percentage & Rank \\
\hline \multicolumn{7}{|l|}{ Long range business planning } \\
\hline No formal long-range business plan & 3 & $4.6 \%$ & 4 & 3 & $5.2 \%$ & 4 \\
\hline Mostly financial and headcount projections & 7 & $10.8 \%$ & 3 & 13 & $22.4 \%$ & 3 \\
\hline More tactical than strategic & 31 & $47.7 \%$ & 1 & 22 & $37.9 \%$ & 1 \\
\hline Clearly strategic in nature & 24 & $36.9 \%$ & 2 & 20 & $34.5 \%$ & 2 \\
\hline \multicolumn{7}{|l|}{ Capital allocation } \\
\hline No formal capital allocation criteria & 3 & $4.6 \%$ & 4 & 4 & $6.9 \%$ & 4 \\
\hline $\begin{array}{l}\text { Formal document stating purpose and level of investment, } \\
\text { but no financial measure of attractiveness }\end{array}$ & 20 & $30.8 \%$ & 2 & 14 & $24.1 \%$ & 3 \\
\hline Rigorous financial analysis for all major & & & & & & \\
\hline expenditures but no post audit & 20 & $30.8 \%$ & 2 & 19 & $32.8 \%$ & 2 \\
\hline Rigorous financial analysis with post audit & 22 & $33.8 \%$ & 1 & 20 & $34.5 \%$ & 1 \\
\hline \multicolumn{7}{|l|}{ Objective setting } \\
\hline No formal setting of individual objectives & 4 & $6.2 \%$ & 5 & 1 & $1.7 \%$ & 5 \\
\hline Only generalized individual objectives are set & 16 & $24.6 \%$ & 2 & 9 & $15.5 \%$ & 3 \\
\hline Highly targeted individual objectives are set & & & & & & \\
\hline but no formal follow-up or appraisal of results & 11 & $16.9 \%$ & 4 & 5 & $8.6 \%$ & 4 \\
\hline Highly targeted individual objectives with strong & & & & & & \\
\hline follow-up & 13 & $20,0 \%$ & 3 & 25 & $43.1 \%$ & 1 \\
\hline $\begin{array}{l}\text { Highly targeted individual objectives with strong } \\
\text { follow-up directly affecting compensation }\end{array}$ & 21 & $32.3 \%$ & 1 & 18 & $31.0 \%$ & 2 \\
\hline
\end{tabular}

Table 9. Organization's degree of maturity (answers to question 20).

Toe et al) have set the capital allocation criteria. Among these, almost two thirds of respondents perform a rigorous financial analysis with (33.8\% in the present study, $34.5 \%$ Teo et al) or without $(30.8 \%$ in the present study, $32.8 \%$ Teo et al) post audit. This results show that most companies perform a serious financial analysis as a part of their planning process.

In the case of clear objective setting, both studies reveal that the majority of respondents set the objectives $(93.8 \%$ in the present study, $98.3 \%$ Teo et al). It is interesting to observe that there is a spread of only $12.3 \%$ among the top three objective settings in the present study; highly targeted individual objectives with a strong followup which directly affects the compensation (32.3\%), only generalized individual objectives $(24.6 \%)$ and highly targeted individual objectives with a strong follow-up $(20 \%)$. This indicates that there is currently a wide variety of objective setting practices in Slovene companies leading us to a conclusion that this area should be better focused on and improved in the future. The Slovene organizations should especially improve the targeting of individual objectives with a strong follow-up since there is a significant gap of $21.8 \%$ between the practices in both countries $(52.3 \%$ in the present study, $74.1 \%$ Teo et al).

\subsection{MIS Department's State of Maturity}

The MIS Department's state of maturity has been evaluated through computer operations, system development, user involvement and feasibility assessment as presented in Table 10 . The results in both studies indicate that the users are generally satisfied with computer operations (85.2\% in the present study, $94.9 \%$ Teo et al). In Slovenia, $14.8 \%$ of respondents stated that the users are dissatisfied with the timeline and accuracy of computer operations. This is clearly a number that is not to be overlooked and computer operations should be the area where the MIS Departments must improve. One reason for dissatisfaction could be that the extent of users participating in the strategic IS planning is very low (1.55 in Table 4) although one of the most important critical factors in the strategic IS planning is having a good user-IS relationships (4.38 in Table 5).

The system development and users involvement parts of the questionnaire are possibly the most 


\begin{tabular}{|c|c|c|c|c|c|c|}
\hline \multirow[t]{2}{*}{ Stage of maturity } & \multicolumn{3}{|c|}{ Present study } & \multicolumn{3}{|c|}{ Teo et al. } \\
\hline & Number & Percentage & Rank & Number & Percentage & Rank \\
\hline $\begin{array}{l}\text { Computer operations } \\
\text { Users are dissatisfied with the timeline } \\
\text { and accuracy of computer operations } \\
\text { Users are generally satisfied with timelines and } \\
\text { accuracy of computer operations but no formal } \\
\text { production statistics is communicated to them } \\
\text { Production control has been formalized, production } \\
\text { objectives are set and performance versus plan is } \\
\text { communicated to users on a regular basis }\end{array}$ & 26 & $42.6 \%$ & 3 & 40 & $67.8 \%$ & 3 \\
\hline $\begin{array}{l}\text { Systems development } \\
\text { No formal standard for systems development exists } \\
\text { Users have little confidence in the MIS group's } \\
\text { ability to deliver major systems on time, within } \\
\text { budget and meeting specifications } \\
\text { Users are very confident of the MIS group's ability } \\
\text { to consistently deliver major systems approximately } \\
\text { on time, within budget and meeting specifications }\end{array}$ & 14 & $21.5 \%$ & 2 & 6 & $10.3 \%$ & 2 \\
\hline $\begin{array}{l}\text { Users Involvement } \\
\text { Users are rarely involved in the systems } \\
\text { development process } \\
\text { Users are involved only as much as necessary to define } \\
\text { the system specifications and to implement them } \\
\text { Users are actively involved in all phases of the } \\
\text { system development process and often manage the } \\
\text { project team }\end{array}$ & 41 & $63.1 \%$ & 3 & 34 & $\begin{array}{l}10.2 \% \\
57.6 \%\end{array}$ & 1 \\
\hline $\begin{array}{l}\text { Feasibility assessment } \\
\text { No formal standard for assessing the feasibility of } \\
\text { proposed major systems development project exists } \\
\text { Feasibility assessments are well defined and } \\
\text { required for all proposed major system development } \\
\text { projects but no post-implementation audit } \\
\text { Feasibility assessments are well defined and } \\
\text { required for all proposed major system development } \\
\text { projects and followed by post-implementation audits }\end{array}$ & 16 & $24.6 \%$ & 2 & 26 & $44.1 \%$ & 1 \\
\hline
\end{tabular}

Table 10. MIS Department's state of maturity (answers to question 21).

questionable in terms of data quality since the respondents in both studies came from the IS Department. Both studies nevertheless show that in the majority of respondents users are very confident about the MIS group's ability to consistently deliver major systems approximately on time, within budget and meeting specifications $(66.2 \%$ in the present study, $79.4 \%$ Teo et al) as well that the users are involved only to define the system specifications and to implement it $(63.1 \%$ in the present study, $57.6 \%$ Teo et al). We must not forget that the questionnaire was filled in by the IS executives though the ratings of the IS Department on MIS performance and the users involvement might therefore be biased.

In the case of feasibility assessment it is very surprising to note that in $24.6 \%$ of Slovene organizations no formal standard for the feasibility assessment of proposed major systems development projects exists. The feasibility studies are nevertheless performed in $75.4 \%$ of the organizations. This percentage should increase in the future since the resource management is of vital importance in today's business environment. 


\section{Conclusion}

The article compares two small countries, but one is developed and the other is in transition. Singapore has an open economy with strong service and manufacturing sectors and excellent international trading links derived from its history. Extraordinarily strong fundamentals allowed Singapore to weather the effects of the Asian financial crisis better than its neighbors, but the crisis did pull GDP growth down to $1.3 \%$ in 1998 from 6\% in 1997. Projections for the 1999 GDP growth are in the $-1 \%$ to $1 \%$ range. Rising labor costs and appreciation of the Singapore dollar against its neighbors' currencies continue to be a threat to Singapore's competitiveness. The government's strategy to address this problem includes cutting costs, increasing productivity, improving infrastructure, and encouraging higher value-added industries. In applied technology, per capita output, investment, and labor discipline, Singapore has key attributes of a developed country.

Slovenia is one of the youngest European countries which became an independent state in 1991 and is a full member of the Central European Free Trade Agreement, a founding member of the WTO, and an associate member of the EU. According to the quality of life, social standard criteria and GDP (10,832 US\$ per capita estimated in 1999), Slovenia is near or even above the European average. Its population is a highly qualified and capable labour force. Slovenia has a well-developed road and railroad network, three international airports, and a large freight port. Slovenia is a country in transition, with some attributes of a developed country. The process of privatisation in Slovenia more or less ended in 1998. Relatively slow process of privatisation of the Slovenian economy has caused a weak "voice of ownership", and the impact of shareholders on changing the business culture toward business renovation has been limited. Most organisations that have existed for more than 10 years have retained hierarchical and "self-governance" features in their business culture. The number of successful corporatewide business transformations has been low and the successful ones have been primarily in "private" corporations. Key problem: In Slovenia and in other developing countries of Central Europe transforming opportunities into business success requires managers with insight, flexibility, and decisiveness.

Although the importance of the strategic IS planning is clearly identified, the study shows that a moderate number $(50.4 \%)$ of Slovene companies are involved in the strategic IS planning. This is surprisingly low if we take into consideration that Teo et al's study reveals $63 \%$ of Singapore companies which performed the strategic IS planning in 1996. The reason for this and some other differences could be the economical and political background of Slovenian organizations.

On the other hand, it is encouraging that those companies that perform the strategic IS planning have corporate and strategic plans aligned $(92.4 \%)$, which enables them to meet overall business plans and goals. The study also shows that the strategic IS planning in Slovenia is still a traditionally oriented process in which top management plays an important role since top managers are the key initiators and participants in the strategic IS planning where which top-down approach is broadly used. This is surprising since we would expect the role of IS management to be significant due to their expert knowledge and experience. On top of sometimes diminished role of IS management, the study shows that $14.8 \%$ of the respondents stated that users are dissatisfied with the timeline and accuracy of computer operations. This indicates that apart from underperforming role of IS management, users involvement in a strategic IS planning is also insufficient (users participation ranked last in the present study), although having a good user-IS relationship is one of the key success factors in the strategic IS planning.

On overall strategic IS planning process is still one of the key business activities where Slovene companies will have to improve in order to be able to effectively participate on the overall global market of the information era. Since we plan to carry out this study every year, it is going to be very interesting to observe how the IS strategic planning process in Slovenia will develop.

We have also plans for our future work. We plan to compare our results with the results of other countries and to perform some additional statistical analyses to investigate the connections between the strategic IS planning and the business performance. 
5. Appendix: the Questionnaire

\section{STRATEGIC IS PLANNING}

1. Does your organization have a strategic IS plan?

$\square$ Yes ले continue with the rest of the questionnaire

$\square$ No 2 please return the questionnaire

2. Time required to develop the strategic IS plan: months

3. MIS budget covered by the strategic IS plan: $\%$

4. Strategic IS plan update frequency:

5. Executive Responsible for Strategic IS Plan?

$\square$ CEO

$\square$ Directors

$\square$ Managers

$\square$ System Engineers

$\square$ Others (Please specify)

6. Highest level within the organization hierarchy whose approval is needed for the strategic IS plan:

$\square$ CEO

$\square$ Boards of Directors

$\square$ Heads of Departments

$\square$ Others (Please specify)

7. Degree of satisfaction with strategic plan $(1=$ low, $2=$ medium, $3=$ high $)$ ?

\begin{tabular}{|l|l|l|l|}
\hline & 1 & 2 & 3 \\
\hline \hline Top management & & & \\
\hline MIS Management & & & \\
\hline User Management & & & \\
\hline
\end{tabular}

8. Which year was the first strategic IS plan developed?

9. Planning methodology used in strategic IS plan:

Bottom-up (MIS system analyst interview users to identify the major decision areas, management and/or operational system needs, possible information gaps and operating inefficiencies that would be improved with information development efforts)

$\square$ Top-down (MIS department identifies projects to be developed by examining the existing organization's business plans for potential support requirements)

Combination of both

$\square$ Others (Please specify)

10. Is the strategic IS plan modeled after the corporate plan?

$\square$ Yes

$\square$ No

$\square$ No Corporate Plan 
11. Are those involved in developing the strategic IS plan made aware of the overall corporate objectives?

○es

$\square$ No

12. Degree of participation in developing strategic IS plan:

\begin{tabular}{|ll|l|l|l|l|}
\hline & HIGH & MEDIUM & LOW & NONE \\
\hline \hline a. & Top Management & & & & \\
\hline b. & Non-MIS Managers & & & & \\
\hline c. & MIS Managers & & & & \\
\hline d. & Users & & & & \\
\hline e. & Computer System & & & & \\
& Programmers & & & & \\
\hline f. & $\begin{array}{l}\text { System Analyst } \\
\text { (Developers) }\end{array}$ & & & & \\
\hline g. & Computer Operations & & & & \\
& Personnel & & & & \\
\hline h. & Vendors & & & & \\
\hline i. & Consultants & & & & \\
\hline
\end{tabular}

Note:

e. Computer System programmers are those responsible for developing systems (or programs) for use by functional departments.

f. Systems analysts are those who evaluate the needs of the users (i.e., the functional departments) and translate these needs into systems for the computer systems programmers to design and develop.

g. Computer operations personnel are those responsible for date input and output activities, hardware maintenance and other allied technical support services.

13. What items are included in your strategic IS plan?

\begin{tabular}{|c|c|c|c|}
\hline & \begin{tabular}{|l} 
INCLUDED \\
IN OUR \\
STRATEGIC \\
PLAN \\
\end{tabular} & \begin{tabular}{|l|} 
NOT \\
INCLUDED \\
BUT \\
SHOULD BE \\
\end{tabular} & $\begin{array}{l}\text { DON'T } \\
\text { BELIEVE } \\
\text { SHOULD BE } \\
\text { INCLUDED } \\
\end{array}$ \\
\hline a. Statements of Objectives & & & \\
\hline b. Projection of possible future MIS environment & & & \\
\hline $\begin{array}{l}\text { c. Projection of possible future user environment } \\
\text { d. Projection of possible future industry environment }\end{array}$ & & & \\
\hline e. Summary of strengths and weaknesses of MIS staff & & & \\
\hline f. Evaluation of past performances vs. plan by MIS & & & \\
\hline $\begin{array}{l}\text { g. Alternate strategy definition/evaluation } \\
\end{array}$ & & & \\
\hline h. Financial plan & & & \\
\hline i. Hardware plan & & & \\
\hline j. $\quad$ Personnel plan & & & \\
\hline k. Education plan & & & \\
\hline 1. Organization plan & & & \\
\hline m. System development plan & & & \\
\hline n. Recommended implementation plan & & & \\
\hline o. Others (Please specify): & & & \\
\hline
\end{tabular}


14. Please weight $(5=$ most important, $1=$ least important $)$ each purpose you had in mind when undertaking your strategic IS planning efforts and then weight the degree of attainment to date $(5=$ outstanding relative to expectation, 1 = poor relative to expectation) in carrying out the strategic IS planning efforts.

\begin{tabular}{|c|c|c|}
\hline & $\begin{array}{c}\text { INITIALLY } \\
\text { DESIRED }\end{array}$ & $\begin{array}{c}\text { DEGREE OF } \\
\text { ATTAINMENT }\end{array}$ \\
\hline a. Identifying new applications & & \\
\hline b. Improving communication with users & & \\
\hline c. Improving communication with top management & & \\
\hline d. Forecasting resource requirement & & \\
\hline e. Identifying internal improvement opportunities & & \\
\hline Improving short-term decision making & & \\
\hline g. Improving the allocation of personnel resources & & \\
\hline Securing budget increases & & \\
\hline Improving morale and sense of purpose & & \\
\hline j. $\quad$ Increasing ROI of new applications & & \\
\hline k. $\quad$ Decreasing costs of computer operations & & \\
\hline 1. Increasing user cooperation & & \\
\hline m. Increasing employee productivity & & \\
\hline n. Increasing top management support & & \\
\hline o. Canceling marginal projects & & \\
\hline p. Increasing visibility of MIS in the organization & & \\
\hline q. Increasing understanding of the organization & & \\
\hline r. Decreasing fire fighting & & \\
\hline
\end{tabular}

15. Please weight $(5=$ most important, $1=$ least important $)$ the importance of 10 crucial factors for success of the Strategic IS Plan.

\begin{tabular}{|c|c|c|c|c|c|}
\hline CRITICAL SUCCESS FACTORS & 5 & 4 & 3 & 2 & 1 \\
\hline Getting top management support for the planning efforts & & & & & \\
\hline Having a clear-cut corporate plan to guide IS planning efforts & & & & & \\
\hline Having good user-IS relationships & & & & & \\
\hline Being able to obtain sufficient qualified personnel to do a proper job & & & & & \\
\hline $\begin{array}{l}\text { Anticipating likely changes in information technology (and } \\
\text { environmental changes) which might affect the strategic IS planning } \\
\text { process }\end{array}$ & & & & & \\
\hline Having a clear, concise, formal, planning procedure & & & & & \\
\hline $\begin{array}{l}\text { Having free communication and commitment to change through the } \\
\text { organization }\end{array}$ & & & & & \\
\hline $\begin{array}{l}\text { Investing sufficient 'front end' time to ensure that all planning tasks } \\
\text { and individual responsibilities are well understood }\end{array}$ & & & & & \\
\hline Deciding on an appropriate planning horizon & & & & & \\
\hline $\begin{array}{l}\text { Taking into account the people and politics side of strategic IS } \\
\text { planning system }\end{array}$ & & & & & \\
\hline
\end{tabular}


16. Please weight $(5=$ most important, $1=$ least important $)$ the benefits from strategic IS planning process.

\begin{tabular}{|l|l|l|l|l|l|}
\hline BENEFITS FROM STRATEGIC IS PLANNING PROCESS & 5 & 4 & 3 & 2 & 1 \\
\hline \hline Improved productivity & & & & & \\
\hline Improved internal coordination & & & & & \\
\hline Efficient and effective management of IS resources & & & & & \\
\hline Improved competitive position & & & & & \\
\hline Greater ability to meet changes in the industry & & & & & \\
\hline Improved quality in products/services & & & & \\
\hline Sound technology path and policies & & & & & \\
\hline Larger market share & & & & & \\
\hline
\end{tabular}

17. Please, indicate the person(s) who initiated strategic IS planning process.

\begin{tabular}{|l|l|}
\hline Top management & \\
\hline IS management & \\
\hline Line (or functional) management & \\
\hline Top and IS management & \\
\hline IS and line management & \\
\hline Top, IS and line management & \\
\hline Missing data & \\
\hline
\end{tabular}

18. Do you have objective measures of IS contribution to productivity?

$\square \quad$ Yes

$\square \quad$ No

19. Please weight $(5=$ most important, $1=$ least important $)$ the importance of developing such measures.

20. Please determine the degree of organization's maturity by placing a check mark beside the most appropriate statement in each category.

\begin{tabular}{|l|l|}
\hline LONG-RANGE BUSSINESS PLANNING & \\
\hline No formal long-range business plan & \\
\hline Mostly financial and headcount projections & \\
\hline More tactical than strategic & \\
\hline Clearly strategic in nature & \\
\hline
\end{tabular}

\section{CAPITAL ALLOCATION}

No formal capital allocation criteria

Formal document stating purpose and level of investment, but no financial measure of attractiveness

Rigorous financial analysis for all major expenditures but no post audit

Rigorous financial analysis with post audit

\begin{tabular}{|l|}
\hline OBJECTIVE SETTING \\
\hline No formal setting of individual objectives \\
\hline Only generalized individual objective are set \\
\hline $\begin{array}{l}\text { Highly targeted individual objectives are set but no formal follow-up or } \\
\text { appraisal of results }\end{array}$ \\
\hline Highly targeted individual objectives with strong follow-up \\
\hline $\begin{array}{l}\text { Highly targeted individual objectives with strong follow-up directly affecting } \\
\text { compensation }\end{array}$ \\
\hline
\end{tabular}


21. Please determine the degree of MIS department's maturity by placing a check mark beside the most appropriate statement in each category.

\begin{tabular}{|c|c|}
\hline COMPUTER OPERATIONS & \\
\hline Users are dissatisfied with the timeline and accuracy of computer operations & \\
\hline $\begin{array}{l}\text { Users are generally satisfied with timelines and accuracy of computer } \\
\text { operations but no formal production statistics are communicated to them }\end{array}$ & \\
\hline $\begin{array}{l}\text { Production control has been formalized, production objectives are set and } \\
\text { performance versus plan is communicated to users on a regular basis }\end{array}$ & \\
\hline SYSTEM DEVELOPMENT & \\
\hline No formal standard for systems development exists & \\
\hline $\begin{array}{l}\text { Users have little confidence in the MIS group's ability to deliver major } \\
\text { systems on time, within budget and meeting specifications }\end{array}$ & \\
\hline $\begin{array}{l}\text { Users are very confident of the MIS group's ability to consistently deliver } \\
\text { major systems approximately on time, within budget and meeting } \\
\text { specifications }\end{array}$ & \\
\hline USERS INVOLVMENT & \\
\hline Users are rarely involved in the systems development process & \\
\hline $\begin{array}{l}\text { Users are involved only as much as necessary to define the system } \\
\text { specifications and to implement it }\end{array}$ & \\
\hline $\begin{array}{l}\text { Users are actively involved in all phases of the system development process } \\
\text { and often manage the project team }\end{array}$ & \\
\hline FEASIBILITY ASSESSMENT & \\
\hline $\begin{array}{l}\text { No formal standard for assessing the feasibility of proposed major systems } \\
\text { development project exists }\end{array}$ & \\
\hline $\begin{array}{l}\text { Feasibility assessments are well defined and required for all proposed major } \\
\text { system development project but no post-implementation audit }\end{array}$ & \\
\hline Feasibility assessments are well defined and required for all proposed major & \\
\hline system development projects and fol & \\
\hline
\end{tabular}

\section{References}

[1] R. Clarke, Strategic Information Systems: Retrospect and Prospect, International Conference on Information Systems and Organisations, Bled, Slovenia, 1992.

[2] D.W. Conrath, S.J.K. Ang, S. Mattey, Strategic planning for Information Systems: A survey of Canadian Organizations, INFOR 30 (1992), 4, 364-378.

[3] T. DAVENPORT, J. Linder, Information Management Infrastructure: the new competitive weapon? Proceedings of the 27th Hawaii International Conference on System Sciences, 1994, 885-896.

[4] GV-in: Business information system of Gospodarski Vestnik, www.gvestnik.si, 2000.

[5] J. JAKLIČ, M. INDIHAR STEMBERGER, T. DAMIJ, J. GRAD, M. GRADIŠAR, A. KOVAČIČ, G. RESINOVIČ, T. TURK, The State of Databases and Data Warehouses in Slovene Organizations, Proceedings of Short Papers, ADBIS'99, Third East-Europen Conference, 1999a, 124-138.

[6] J. JAKLIČ, M. INDIHAR STEMBERGER, T. DAMIJ, J. GRAD, M. GRADIŠAR, A. KOVAČIČ, G. RESINOVIČ, T. TURK, Stanje poslovne informatike $v$ slovenskih podjetjih: izhodišča in prvi rezultati raziskave, Uporabna informatika, 7 (1999b), 1, 44-50.
[7] J. KARIMI, Y. P. GuPTA, T. M. SOMERS, Impact of Competitive Strategy and Information Technology Maturity on Firm's Strategic Response to Globalisation, Journal of MIS, 12 (1996), 55-88.

[8] A. KovAČIČ, Information Technology as an Enabler to Enterprises in Transition, Proceedings of The Third International Conference 'Enterprise in Transition', University of Split, Split-Sibenik 1999, 278-290.

[9] A. L. Lederer, V. Sethi, Key Prescriptions for Strategic Information Systems Planning, Journal of MIS, 13 (1996), 35-62.

[10] A. L. LEDERER, H. SALMELA, Toward a Theory of Strategic Information Systems Planning, Journal of Strategic Information Systems, (1996), 237-253.

[11] E.R. MCLEan, J.V. SodEN, Strategic Planning for MIS, Wiley, New York (1977).

[12] F. N. PAVRI, J. S. K. ANG, A study of the strategic planning practices in Singapore, Information and Management, 28 (1995), 33-47.

[13] M. E. PORTER, Competitive Advantage: creating and sustaining superior performance, Free Press, New York, 1985. 
[14] Register of Organizations (Register of Organizations, 1998).

[15] Slovene Corporate Law (Zakon o gospodarskih druzbah), Uradni list RS-30/93(1993), Ljubljana.

[16] Slovenia in Figures '99, Statistical Office of the Republic of Slovenia, www.sigov.si/zrs, 2000.

[17] Statistics Singapore, http://www.singstat.gov.sg/

[18] T. S. H. TeO, J. S. K. Ang, F.N. PavRI, The state of strategic IS planning practices in Singapore, Information and Management 33 (1997), 13-23.

[19] G. TORKZADEH, W. XIA, Managing Telecommunications by Steering Committee, MIS Quarterly, 16 (1992), 187-199.

The questionnaire in English is enclosed in the appendix Its address is http://www.ef.unilj.si/projekti/informatika General explanation of all analyzed topics can be found in the enclosed questionnaire (see appendix).

Received: September, 1999 Revised: July, 2000

Accepted: September, 2000

Contact address

Andrej Kovačič

Aleš Groznik

Jurij Jaklič

Mojca Indihar Stemberger

University of Ljubljana

Faculty of Economics

Kardeljeva ploščad 17

SI-1000 Ljubljana, Slovenia
ANDREJ Kovačič received his $\mathrm{PhD}$ in Information Science from the University of Ljubljana in 1992. In the past 10 years he was project and business manager at the company PRIS Consultung and lecturer at the Faculty of Economics and at the School of Public Administration. $\mathrm{He}$ is organiser and chairman of annual Conferences on Information $\mathrm{R} \& \mathrm{D}$, founding president and member of the Association for Informatics at Slovenian Chamber of Commerce, member of editorial board of "Uporabna informatika" magazine and member of Slovene Society for Informatics.

ALEŠ GROZNIK is a junior faculty member in the Department of Information Sciences at the Faculty of Economics, University of Ljubljana. He holds a first degree and an M.Sc. in Engineering and an M.Sc. in Information Sciences from the University of Ljubljana. He has extensive industry experience in management and strategic information systems gained working as financial and information technology associate for several multinationals. His research interest is in the areas of information system role within the broader context of corporate objectives, management and strategic information system planning, information technology productivity, and information technology management in national and international environments.

JURIJ JAKLIČ received his Master in Computer Science degree in 1992 from the University of Houston, USA, and his Ph.D. in 1997 from the University of Ljubljana, Slovenia. Currently he works for the University of Ljubljana, Faculty of Economics as a junior faculty member. His main research interest is data and business rules modeling. He is member of the Slovene Society for Informatics and International Association of Computer Information Systems (IACIS).

MOJCA INDIHAR STEMBERGER received her Master in Computer and Information Science degree in 1996 from the University of Ljubljana. Currently she is a junior faculty member at the University of Ljubljana, Faculty of Economics. She is preparing Ph.D. thesis. Her research interests include object-oriented methodologies, databases and business process reengineering. She is member of the Slovene Society for Informatics, Slovene Society for Mathematics and International Association of Computer Information Systems (IACIS) 